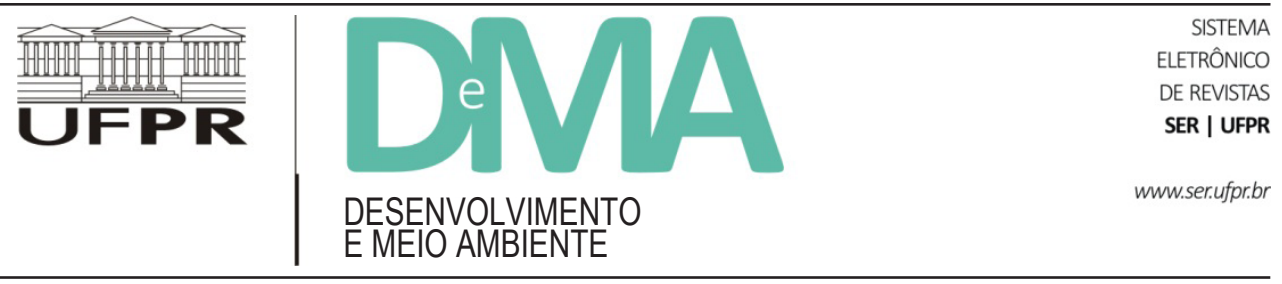

\title{
Traditional Knowledge of the Fishermen of the Lower Juruá River: Understanding the Reproductive Patterns of the Region's Fish Species
}

\section{Conhecimento tradicional dos pescadores do baixo rio Juruá: aspectos relacionados ao comportamento reprodutivo dos peixes da região}

\author{
Tony Marcos Porto BRAGA ${ }^{1 *}$, George Henrique REBÊLO² \\ ${ }^{1}$ Universidade Federal do Oeste do Pará (UFOPA), Santarém, PA, Brasil. \\ ${ }^{2}$ Laboratório de Manejo de Fauna, Instituto Nacional de Pesquisas da Amazônia (INPA), Manaus, AM, Brasil. \\ *E-mail of contact: fishportony@hotmail.com
}

Article received in January 20, 2016, final version accepted in March 22, 2017.

\begin{abstract}
The present study describes the knowledge system of riverside fishing communities in the lower Juruá river Extractivist Reserve in the Brazilian state of Amazonas, focusing on the understanding of the reproductive patterns of the region's fish species. The data were collected in 2008 and 2009 during the low water period, when the most experienced fishermen gather to count and harvest the pirarucu (Arapaima gigas). Data were collected using semi-structured interviews of the fishermen considered to be local "authorities". The data were analyzed by allocating the content of the responses to the interviews to specific categories. The data were also analyzed through an emic/etic approach, based on the compilation of cognitive tables, which compare the traditional knowledge with the content of the pertinent scientific literature. The fishermen presented an extensive and detailed knowledge of the reproductive behavior of the region's fish species, relating observed patterns to the flood pulse of the Juruá River.
\end{abstract}

Keywords: ethno-ecology; riparian fisherman; fishing; reproductive patterns.

RESUMO: O presente trabalho analisa o conhecimento que os pescadores ribeirinhos residentes nas comunidades localizadas na Reserva Extrativista do baixo rio Juruá possuem sobre o comportamento reprodutivo dos peixes da região. Os dados foram coletados em 2008 e 2009, sempre no final do período de vazante, quando os pescadores mais experientes estavam reunidos para a realização da contagem e despesca do pirarucu (Arapaima gigas). Fez-se uso de entrevistas semiestruturadas aplicadas aos pescadores considerados "autoridades" locais quanto à pesca. A forma de análise dos dados obtidos nas entrevistas foi a categorização do conteúdo das respostas. Os dados também foram trabalhados por meio de uma abordagem emicista/eticista, elaboração de tabelas de cognição comparada, em que os conhecimentos tradicionais são comparados com trechos da literatura cientifica 
corrente. Os pescadores demonstraram possuir um extenso conhecimento sobre o comportamento reprodutivo dos peixes da região, relacionando-o sempre ao ciclo hidrológico do rio Juruá.

Palavras-chave: etnoecologia; pescador ribeirinho; pesca; reprodução.

\section{Introduction}

Traditional Knowledge refers to a unique form of understanding of the specific local conditions which affect the subsistence and development of rural communities following a traditional lifestyle. These knowledge systems are accumulative and represent the end product of countless generations of personal experiences, careful observation, and constant experimentation. This type of knowledge has been studied from a number of different perspectives, in particular through the analysis of the classification systems used to catalog natural resources, their uses, and harvesting, based on appropriate management techniques, accumulated knowledge, perceptions or even beliefs (Berlin, 1992; Mourão \& Nordi, 2003).

All these studies have helped to elucidate relatively sophisticated knowledge systems, which are within the intellectual domain of traditional populations, and have contributed to the consolidation of the Ethnosciences, which has been marked by the emergence of new paradigms (in particular interdisciplinarity) and the loss of old biases, in particular ethnocentrism. The present-day ethnosciences have emerged from a consolidated and interdisciplinary scientific field, rather than a simple association of disciplines, a field which integrates knowledge systems and generates new research approaches (Marques, 2002).

The ethnosciences have generated a number of specific fields of research, including Ethnobiology, which draws primarily on Socio-Linguistics, and structural and cognitive Anthropology (Morán, 1990). Given its interdisciplinary nature and recent theoretical and methodological advances, Ethnobiological research can call on analytical tools from a number of different fields, such as Anthropology, Botany, Zoology, Ecology, History, Geography, Linguistics, and Taxonomy.

Berlin (1992) assumed that ethnobiological classification is guided by perception. Other authors, such as Silvano and Begossi (2001) and Souto and Martins (2009) consider that ethnobiological knowledge is influenced primarily by the usefulness of the organisms to the classifiers, with more complex and detailed classifications being established for the animals and plants that are most relevant to the survival of the population.

Recent research has shown that informal situations are also an important source of ethnobiological data, permitting the identification of the "memes" of the region or cultural group being analyzed. These memes may be ideas or parts of ideas, esthetic and moral values, or any other type of information that may be easily learned, selected, and transmitted (Waizbort, 2003). The analysis of the process of acquisition through which this information is assimilated is important for the understanding of the reference values and world view of the classifier, as well as guaranteeing that the opinion, beliefs, and world-view of the observer do not interfere with the interpretation of the data (Souto \& Martins, 2009).

Given all these considerations, the present study focuses on the traditional knowledge of the fishermen of the Lower Juruá Extractivist Reserve 
in the Brazilian state of Amazonas. From an ethno-ecological perspective, the study evaluates local knowledge on the biology, ecology, and reproductive behavior of the principal fish ethnospecies exploited by the fishermen, and describes the traditional classification system used by them to organize their knowledge.

\section{Material and methods}

In July, 2008, the present study received license number 16511-1 for scientific research from the SISBIO system of the Brazilian federal environment institute (IBAMA/ICMBio) and license number 181/08 from the Research Ethics Committee of the National Amazon Research Institute (INPA) authorizing research within the area of the Lower Juruá Extractivist Reserve (03 $28^{\prime} 12,0^{\prime \prime} \mathrm{S}$; $66^{\circ} 04^{\prime} 06,7^{\prime \prime} \mathrm{W}$ ) (Figure 1). As in other parts of the Amazon, the artisanal fisherman who reside within this RESEX obtain their principal source of animal protein from these fishing resources, both for consumption and for sale, and the success of their activities directly depends on the local variations in the level of the Juruá River and on the knowledge that they possess of the biology and ecology of the target species.

In the same year, the first author received an invitation from Rural Workers Association of the Lower Juruá (ASTRUJ) to participate in the management of the reserve's population of pirarucu (Arapaima gigas) which involved activities ranging from counting individuals to the capture process known locally as the "pirarucu harvest". This activity normally begins at the end of the ebb period, in August, and continues throughout September. The most experienced fishermen of each community are invariably present during this activity, which permitted the collection of additional data for the present study.

Data were collected using semi-structured interviews, which permit the modification of the approach, depending on the response of the subject, allowing the inclusion of new items or structure, as deemed fit by the interviewer (Minayo, 1998). In general, the model proposed by Posey (1987) and Marques (1991) was adopted, in which the interviewees respond to the questions according to their own perceptions, with the fewest possible restrictions. This approach allows the interviewer to use expressions emitted by the subject to formulate new questions or lines of enquiry (during the interview or afterwards) for the collection of additional or complementary information, or to evaluate the consistency of responses among the different informants, in order to produce idea "memes". These memes were used in the present study as an essentially qualitative tool for the evaluation of the consistency of the information provided by the interviewees (Souto \& Martins, 2009).

Initially, nine specialists involved in the management of the pirarucu stocks were interviewed. All the interviews were recorded by taking details notes, although in five cases, involving the individuals considered by their peers to be the most experienced, the interviews were recorded for subsequent transcription using the Voice Editing program (version 2.00 Premium Edition 2004-2007). This slightly different approach was adopted in these cases in order to ensure that all the fine details of the knowledge of these individuals were recorded.

Further interviews were conducted in February, 2009, and during the pirarucu management period in both the main town and the local communities. The initial interviews had provided a list of specialists, who were the focus of this new survey. This approach, which is known as the "snowball" 


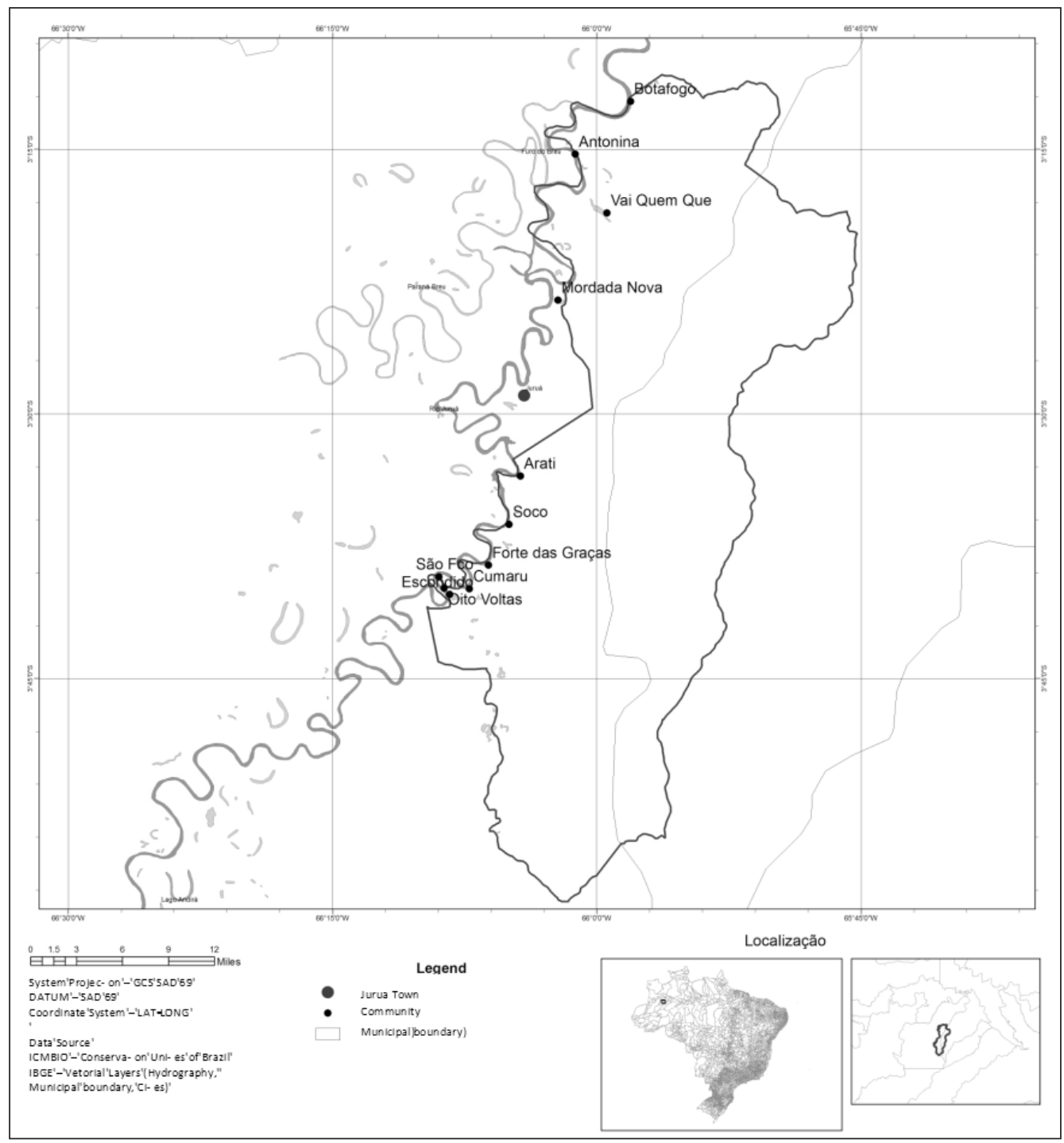

FIGURE 1 - Location of the Lower Juruá Extractivist Reserve (black outline) and the communities monitored during the present study.

SOURCE: Laboratory of the geoprocessing and environmental analysis of the Federal University of Western Pará.

method (Bailey, 1982), consists of requesting, at the end of the interview, that the informant indicates one or more fishermen from his community, such as the most experienced or those that depend most on fishing for their livelihood, who should also be interviewed.

All the interviewees considered to be specialists or key informants were interviewed a second 
time with semi-structured questionnaires including questions on the characteristics of the fishes, the habitats they occupy, their feeding behavior, the best fishing technique, seasonal patterns, reproduction, and the identification of ethnospecies. During this approach, the interviewees were shown catalogs with images of the principal fish species known to occur in the region, which were presented in a random order (Berlin, 1992; Silvano \& Begossi, 2001). This approach is designed for the acquisition of both qualitative and quantitative data on local knowledge. Overall, 27 key informants were interviewed.

The data collected were stored at the INPA Fauna Management Laboratory, where they were fed into an Access database. The records were broken down and classified as information on: (a) social relationships in fishing, (b) reproductive characteristics, (c) feeding ecology, (d) growth and mortality, (e) distribution, (f) behavior patterns and their functions. For analysis, the qualitative data were classified in categories according to their content (Minayo, 1998). This approach demands the definition of categories that are not only exclusive, but also consistent in terms of their elements, ideas, and expressions. An emic/etic approach was also adopted for the analysis of the data, through the construction of cognitive tables similar to those produced by Marques (1991), in which the traditional knowledge offered by the informants is compared with the relevant information available in scientific texts.

The scientific classification of the fish species was based on the specialized literature and identification keys for the region's fauna (Ferreira et al. 1998; Santos et al. 2006). Only one species could not be identified reliably in this way, and it was confirmed by the specialist Dr. Geraldo Mendes dos Santos at INPA.

\section{Results}

Based on the understanding of reproductive events and the consistency of the definitions of memes, the fishermen classified the fish species in two ethological ethnocategories, the fishes that "spawn in the river" and those that "spawn in lakes". The fishermen from the communities on the Andirá River defined a third category - species that do not leave the blackwater tributaries, and do not pass through the lakes, to spawn in the Juruá River, such as the disk tetra, known locally as the "pacu do olhão" (Myleus schomburgkii:) which "spawns in November, down there in the weak currents of the Andira', they don't come out of the river to spawn" and the "piau" (Anostomidae), which "spawns when the streams begin to fill up, in January, some of them spawn in the main stream, it's really chaotic" (Mr. A., resident of the Igarapé Branco community). These perceptions are exemplified in Table 1, which summarizes the traditional local knowledge on the reproduction of the pacu (Mylossoma spp.), one of the migratory species most often mentioned by the fishermen, and the peacock bass, known locally as the "tucunaré" (Cichla spp.), a sedentary fish.

In general, the interviewees characterized the spawning period of the species in relation to the annual flood pulse of the Juruá River (Figure 2 ). According to the model conceived by the local fishermen, the most important fish species captured in the reserve begin to spawn during the flood (rising water) period, which lasts from November to March. Considerable variation in the flood pulse is also observed between years, however (Figure 2 ), which has a direct effect on spawning patterns.

All the ethnospecies identified by the fishermen are assumed to have a single annual spawning period. According to the specialists from the Andirá 
TABLE 1 - Traditional ecological knowledge on the reproductive behavior of the pacu (Mylossoma duriventre and Mylossoma aureum) and tucunaré (Cichla monoculus).

\begin{tabular}{ll}
\multicolumn{1}{c}{ Pacu (migratory) } & \multicolumn{1}{c}{ Tucunaré (sedentary) } \\
$\begin{array}{l}\text { The pacu moves out with the jaraqui, in December, they all go } \\
\text { to the white water. }\end{array}$ & $\begin{array}{l}\text { The tucunaré spawns on submerged trunks and branches, } \\
\text { and sometimes digs a small hole in the river bottom. }\end{array}$ \\
\hline $\begin{array}{l}\text { The pacu goes out into the river, just like the sardinha and the } \\
\text { jaraqui. }\end{array}$ & $\begin{array}{l}\text { In December, the tucunaré is spawning on submerged } \\
\text { branches in the lakes }\end{array}$ \\
\hline The pacu spawns in the river, and as far as I know, just once & $\begin{array}{l}\text { The fishes spawn on the timbers at the margin of the lake. } \\
\text { a year. }\end{array}$ \\
$\begin{array}{ll}\text { They spawn in December and January, and then they go out } \\
\text { into the river, mixed up with the jaraqui and matrinxä, all }\end{array}$ & $\begin{array}{l}\text { the fry hatch, and then he takes them around with him, just } \\
\text { together, they go and spawn in the mouth of the Andirá. }\end{array}$ \\
\hline
\end{tabular}

SOURCE: Elaborated by the authors.

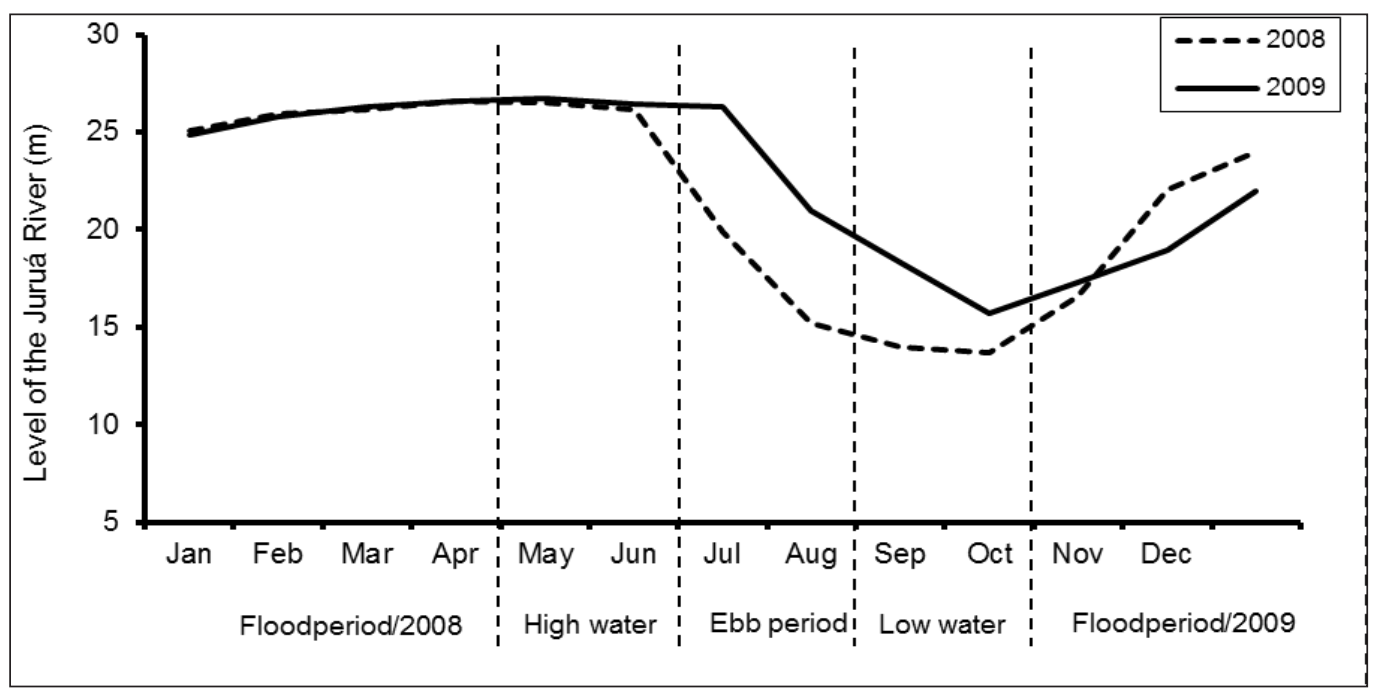

FIGURE 2 - Monthly variation in the level of the Juruá River at the Forte das Graças station, showing the seasonal periods defined for the present study.

SOURCE: Elaborated by the authors.

region, only the tucunare spawns more than once a year, given that they are found "brooding, we always see them with their young!" (Mr. C., resident of the Cumaru community) during both the flood and ebb periods.

The specialists nevertheless referred to the possibility that the different spawning periods represent the behavior of more than one species of the genus Cichla, as confirmed by one of the interview- ees - "let's just say that there may be three different types of tucunaré that spawn here, although I can't say if one type spawns during the flood and the other during the ebb because no-one really knows. The common one, the big yellow one, they start spawning as soon as the flood starts, in October or November" (Mr. G., resident of the Cumaru community). In fact, two species of tucunaré were identified during fieldwork in the Andirá region, the 
common peacock bass, Cichla monoculus (identified as the "common" or "big yellow" tucunaré) and the closely-related speckled pavon, Cichla sp.

The ethno-ecological model of the reproductive behavior of the fish species of the lower Juruá provided by the fishermen is shown in Table 2 .

The species were also classified in terms of the size of their spawn, as fishes that either "lay many eggs" or "lay few eggs", with the latter characteristic being related to the occurrence of paternal behavior. The species that produce abundant spawn include the pacu and the matrinxão (Brycon ama- zonicus), while the brooders include the aruanã or silver arowana (Osteoglossum bicirrhosum), the cará (Cichlidae), and the tucunaré.

"I think that the tucunaré only produces about 200 fry, which accompany the male until they reach a certain size, and then they look after themselves" (Mr. D., resident of the Forte das Graças community).

"In comparison with the matrinxão, the tucunaré lays very much fewer eggs, but on the other hand, the matrinxão does not care for its young" (Mr. D., resident of the Botafogo community).

TABLE 2 - Ethno-ecological model of the reproductive behavior of the fish species of the lower Juruá River.

\begin{tabular}{|c|c|c|}
\hline $\begin{array}{l}\text { BEHAVIOR } \\
\text { CATEGORY }\end{array}$ & CATEGORY IN THE ETHNO-ECOLOGICAL MODEL & ETHNOSPECIES \\
\hline \multirow[t]{2}{*}{ Migration } & Species that spawn in the river (migrants) & $\begin{array}{l}\text { Pacu, matrinxão, jaraqui, pirapitinga, } \\
\text { curimatã, tambaqui, sardinha, } \\
\text { branquinha, surubim }\end{array}$ \\
\hline & $\begin{array}{l}\text { Species that spawn in the lake } \\
\text { (non-migrants) }\end{array}$ & Aruanã, tucunaré, pirarucu, piranha \\
\hline \multirow{4}{*}{ Spawning site } & In the river at the mouth of the stream & $\begin{array}{l}\text { Jaraqui, pacu, matrinxão, sardinha, } \\
\text { pirapitinga, branquinha, Curimatá }\end{array}$ \\
\hline & In reeds in lake outlet channels & Sardinha, pacu, aracu comum \\
\hline & At the "tip of the water" & Matrinxão \\
\hline & On submerged trunks and branches at the lake margin & Tucunaré, piranha, cará \\
\hline \multirow{2}{*}{ Parental care } & Accompanies the fry and defends them from predators & Tucunaré, pirarucu \\
\hline & Gets broody, until the fry leave & Tucunaré, piranha caju, tamboatá \\
\hline \multirow[t]{3}{*}{ Sexual dimorphism } & The male is longer and thinner, the female, more portly & $\begin{array}{l}\text { Matrinxão, jaraqui, curimatá, } \\
\text { tambaqui, pirapitinga, branquinha }\end{array}$ \\
\hline & The female is always lighter in color & Tucunaré, pacu, pirarucu \\
\hline & The male has that big lump on its head & Tucunaré \\
\hline \multirow[t]{2}{*}{ Ethology } & Makes a buzzing noise & Piau, branquinha, curimatá, jaraqui \\
\hline & Courts and forms a pair & Tucunaré, piranha, pirarucu \\
\hline
\end{tabular}

SOURCE: Elaborated by the authors. 
In most cases, the species go out into the river to spawn. The fishermen described a number of distinct microhabitats, such as the meeting of the whitewater of the Juruá River with the clear or black waters of the creeks which is associated with the presence of a lake in most cases. Floating reed beds are another type of microhabitat, in which species such as pacus and aracus (Anostomidae) leave their eggs "stuck" to the vegetation. The fishermen referred to one microhabitat as the "tip of the water", which is an area of the river which "flows very rapidly and is like a waterfall" and is used at some moments during the spawning of the pirapitinga (Piaractus brachypomum).

"The pirapitinga just needs flowing white water to spawn, and it lays its eggs in the canarana, right there in the river" (Mr. $\mathrm{W}$, resident of the Botafogo community).

The movements of the fish populations that allow them to spawn in the rivers were described in detail and referred to as "spawning migrations", a behavior pattern described in the scientific literature. The spawning migration was described as a cycle that begins when the river starts receding, when the fish inhabiting the swamp (igapó) forest or flooded streams, in the case of the matrinxãos and pirapitinga, move towards the lakes, where they aggregate in migratory shoals. These shoals then move out into the whitewater river to spawn during the high water period. Finally, the juveniles return to the lakes and the adults to the lakes and swamps (igapós) during the flood period, when the whole cycle begins again (Figure 3).

During this period, which may last from November to January, depending on the speed of the flooding, many characiform species are caught, during an activity known as the "harvesting of the spawned fish".

"When the river is rising, the choronas leave the lake and goes into the river to spawn, and then

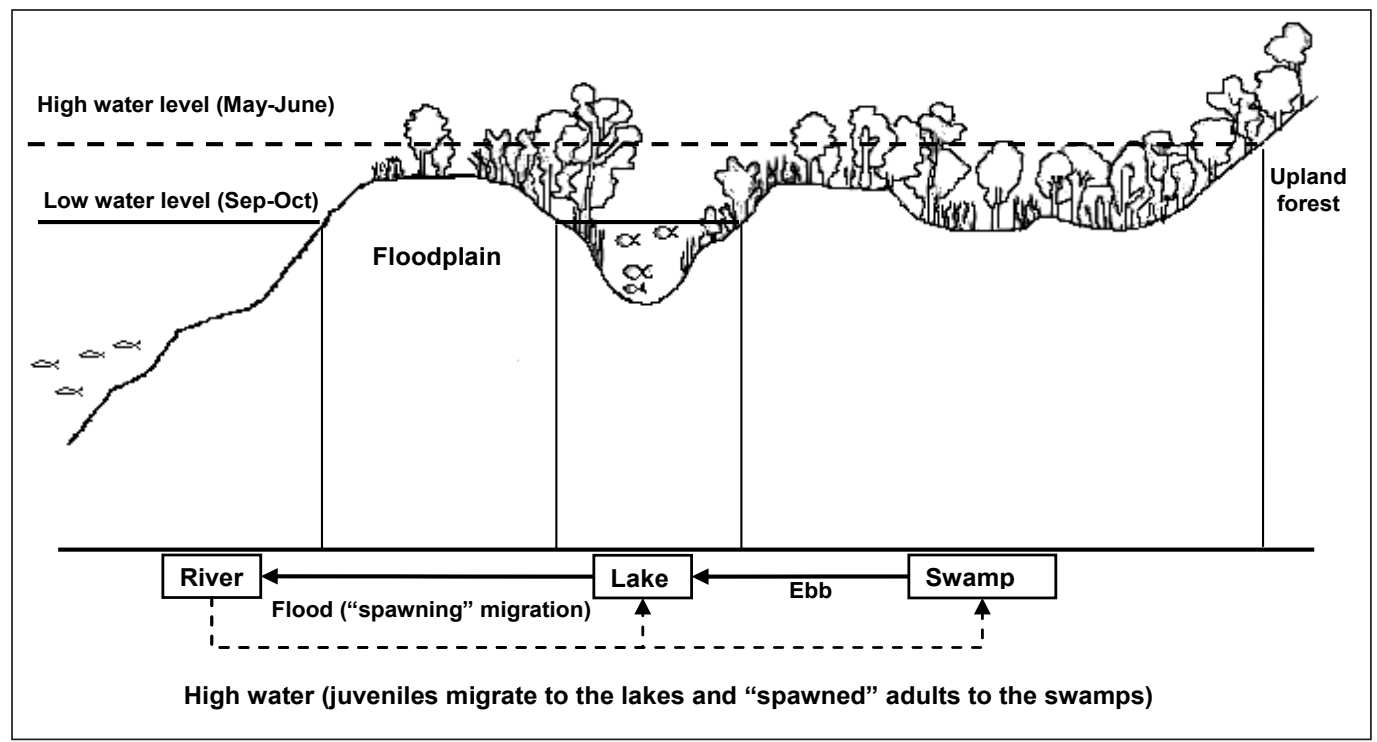

FIGURE 3 - Profile of the flood pulse on the Juruá River and the principal habitats involved in the spawning migration of the local fish species.

SOURCE: Elaborated by the authors. 
they return. I think they return to get away from all the animals that live in the river" (Mr. R., resident of the Forte das Graças I community).

The tucunaré and pirarucu were the species mentioned most frequently by the fishermen in relation to parental care. For example, "The tucunaré gets really audacious, he incubates the eggs until the fry hatches and then they accompany him. He even keeps them inside his mouth, he does" (Mr. V, resident of the Cumaru community).

The tucunaré was also the species cited most often in relation to sexual dimorphism, referring to the "lump" that forms on the head of the male. Ethnospecies such as the matrinxão, curimatá or black prochilodus (Prochilodus nigricans), and the jaraquis (Semaprochilodus spp.) were also mentioned here, due to the fact that the males are relatively "long and thin" in comparison with the females. In general, the information provided by the fishermen on the reproductive behavior of the fishes of the lower Juruá was consistent with the data available in the scientific literature (Table 3).

\section{Discussion}

The forms in which an animal behaves and interacts with its natural environment have a major influence on its reproductive success. As a group,

TABLE 3 - Cognitive considerations on the reproductive biology of fishes on the lower Juruá in comparison with the data available from the scientific literature.

\begin{tabular}{|c|c|}
\hline Quote from interviews & Information from the literature \\
\hline $\begin{array}{l}\text { We can get an Idea of which sex the fish is because the } \\
\text { male (tucunaré) has that big lump here on its back, and the } \\
\text { female doesn't. }\end{array}$ & $\begin{array}{l}\text { In captivity, the male Cichla monoculus, presents a } \\
\text { protuberance similar to the hump of a zebu bull during the } \\
\text { breeding season (Fontenele, } 1948 \text { apud Isaac et al., 2000). }\end{array}$ \\
\hline $\begin{array}{l}\text { The pacu goes out into the river with the jaraqui in } \\
\text { December, they all go into the white water [...] this year, } \\
\text { the matrinxão all came out in the same way, starting in } \\
\text { December and continuing into January, they all came out } \\
\text { from the Andirá into the Juruá. }\end{array}$ & $\begin{array}{l}\text { The short life cycle ( } r \text {-strategist) species include the jaraqui, } \\
\text { curimatã, branquinha and others. These species normally } \\
\text { migrate from one river to another to spawn (Santos \& Ferreira, } \\
\text { 1999). }\end{array}$ \\
\hline $\begin{array}{l}\text { The piranha caju doesn't go into the river, it spawns right } \\
\text { there in the swamp when the water is rising in February. I } \\
\text { reckon they must take care of the young because they only } \\
\text { come out of the swamp when the fry have grown up. }\end{array}$ & $\begin{array}{l}\text { Of the nest-guarding characids, the Serrasalmus species } \\
\text { spawn during the main rainy season in Guyana, where they } \\
\text { are known to guard the eggs deposited on tree roots to prevent } \\
\text { them from being washed away (Lowe-McConnel, 1999). }\end{array}$ \\
\hline $\begin{array}{l}\text { We can find the tucunare in its nest at the end of September, } \\
\text { they spawn right there in the nest they make on the bottom }\end{array}$ & $\begin{array}{l}\text { The sedentary or lacustrine species spend their lives mainly } \\
\text { in the lakes or associated aquatic systems (Barthem \& Fabré, } \\
\text { 2004). }\end{array}$ \\
\hline $\begin{array}{l}\text { we can find them spawned in November. We can find them } \\
\text { with the fry in their mouths, down in the lake. }\end{array}$ & $\begin{array}{l}\text { The male silver arowana guards the fertilized eggs and } \\
\text { then mouthbroods the fry until they are capable of feeding } \\
\text { themselves in the external environment (Cavalcante, 2004). }\end{array}$ \\
\hline $\begin{array}{l}\text { The tucunare must spawn at least a couple of times, I think, } \\
\text { because we always see them with infants. }\end{array}$ & $\begin{array}{l}\text { In general, the species that spawn more than once per year } \\
\text { have low reproductive rates, parental care, and do not migrate. } \\
\text { These K-strategist species include the pirarucu, tucunaré, and } \\
\text { cará (Santos \& Ferreira, 1999). }\end{array}$ \\
\hline
\end{tabular}

SOURCE: Elaborated by the authors. 
the teleosts are able to occupy a variety of environments due to their varied reproductive modes, which include extreme behavioral strategies. The considerable variation in life history strategies and reproductive modes allows the teleosts to adapt to environments in which both biotic and abiotic conditions vary considerably over time and space. The reproductive success of each individual and the adaptive value or viability of its offspring will determine the eventual composition of the gene pool of subsequent generations (Vazzoler, 1996; Del-Claro, 2004).

There are few works found for this region and with this theme. Braga and Rebêlo (2014) analyzed the knowledge that the resident traditional populations located in the Extractive Reserve of the Lower Juruá River possess on aspects related to feeding behavior of fish in the region. The authors noted that fishermen demonstrated extensive knowledge on the feeding behavior of the fish in the region, in addition to their predators, always relating this to the function of the hydrological cycle and their stage of life.

Ethno-ichthyological studies in other regions of Brazil have revealed a detailed understanding of important aspects of the reproductive, migratory, and territorial behavior of fishes, which, in some cases, is more finely-detailed than the information available in the scientific literature (Mourão \& Nordi, 2003). The fishermen of the Extractive Reserve of the Lower Juruá River are equally knowledgeable about the reproductive seasonality, spawning sites, migratory and parental behavior, and sexual dimorphism of the local fish species.

The ecological and behavioral characteristics of Amazonian fish species can be divided into three principal groups - sedentary species, which are typically associated with lacustrine systems, migratory species, which are found in both lakes and rivers, and long-distance migrants, which are associated primarily with the main channels of the basin's major rivers (Barthem \& Fabré, 2004). In the present study, the fishermen were able to provide more detailed information on the species of the first two groups, which are divided between the fishes that "spawn in lakes" (sedentary species) and those that "spawn in the river" (migrants).

One other important detail provided by the local fishermen was the formation of migratory shoals in the lakes. These shoals are formed by fishes of the same species, and function primarily as protection against predators, while also guaranteeing access to reproductive partners and increasing foraging efficiency. In a study of artisanal fishermen in the Mamanguape Estuary in the Brazilian state of Paraíba, Mourão and Nordi (2003) recorded the term "fishes that move in blankets", which refers to the species that form shoals. This emic category is also used by the specialists of the lower Juruá, who affirmed that these shoals are formed by fishes of the same or "related" species.

With the exception of the tucunare, the local specialists confirmed that all the ethnospecies spawned only once a year. In a study of the gonadal condition of a number of different species on the middle Amazon River, Isaac et al. (2000) confirmed that the tucunare (Cichla monoculus) reproduces in March and April. However, they also observed some mature (stage II) individuals in subsequent months, and concluded that the species may have a longer breeding season, or even spawn a number of times over the course of the year. Gomiero and Braga (2004) studied breeding patterns in two Cichla species introduced into a reservoir in southeastern Brazil, and found evidence (analysis of the oocytes) of staggered spawning, and also that Cichla monoculus was more fertile than Cichla ocellaris. These findings support the information provided by the 
fishermen in the present study, who confirmed that the tucunare spawns more than once a year. This conclusion is further reinforced by the findings of Santos et al. (2006), who confirm that the tucunaré, like most other cichlids, forms breeding pairs, which build nests and care for their offspring, and also present staggered breeding, that is, they spawn more than once a year.

There are clear differences between the Amazonian fish species that spawn once or multiple times per year (Santos \& Ferreira, 1999). The single spawners release large quantities of gametes into the water column, where fecundation occurs. These species, such as the jaraquis, curimatãs, branquinhas, pacus, and matrinxãs, tend to be short-lived with high reproductive rates, characteristics typical of $r$-strategists. Most of the species targeted by fisheries in the Amazon basin are of this type, and are characterized by high rates of growth and reproduction, which tend to spawn during periods when food and refuges are abundant, that is, during the flood season (Barthem \& Fabré, 2004). All these characteristics are typical of the species that the local fishermen refer to as "fishes that lay large quantities of eggs". By contrast, the multiple-spawners tend to have low reproductive rates and parental care, and are sedentary (K-strategists). These are species like the pirarucu, tucunarés, and acarás, which are "fishes that lay few eggs".

Most of the species analyzed in the present study spawn in the river. In their analysis of the distribution of fry and juveniles in rivers with different nutrient loads, Lima and Araujo-Lima (2004) concluded that whitewater rivers, such as the Juruá, which are rich in nutrients, and the associated várzea swamps represent important nursery environments for many Amazonian fish species.

The flooded forests of the Amazon basin are referred to by a number of common names. In Bra- zil, the two most common types are referred to as "várzeas" and "igapós". In the Mamirauá Reserve in Tefé (Amazonas state), the local inhabitants refer to areas flooded during short periods as várzeas, while areas that are flooded for much longer periods, or even permanently, as referred to as igapós (Ayres, 1993). This same classification is used by the residents of the lower Juruá, independently of the color of the water.

A number of new questions and doubts are a typical result of any study based on an emic/etic approach (Marques, 1991). In the present study, one major gap in the knowledge of the local specialists was on the reproductive behavior of the tambaqui. While this is one of the preferred species in the study area, none of the specialists could identify its spawning grounds, especially as it was the fish least often caught after spawning. Knowledge on the maturation of this species was based on the information handed down by the ancestors of the present-day specialists, who lived on the Juruá during the period when the tambaqui was "plentiful, and adult tambaquis would form large shoals in the river". This historical information is especially important, given the current decline in tambaqui populations, which have been overfished drastically in many parts of the Amazon basin (Araújo-Lima \& Goulding, 1998), a process that also appears to be occurring on the Juruá.

\section{Conclusions}

a) The fishermen of the Lower Juruá Extractivist Reserve have a detailed traditional knowledge system which is consistent with the scientific literature available on the region's sedentary and migratory fish species, especially with regard to: shoaling 
and spawning migrations, spawning habitats, parental behavior and frequency of spawning;

b) The fishermen described in detail the reproductive cycle of the different fish species, which they related to the flood pulse of the Juruá River, and secondarily to the months of the year;

c) All knowledge the fishermen about tambaqui were based on information obtained from their ancestors. The fishermen had no current information on the reproduction of the species, despite affirm what tambaquis were captured and consumed regularly. This situation is worrying because it is increasingly difficult to find adult specimens of tambaqui, one fish of the most exploited in the Amazon basin and that shows signs of over-fished;

d) The fishermen have good traditional knowledge of the distribution and movements of the principal species they harvest, and this information is applied directly to their fishing activities.

\section{Acknowledgments}

We are grateful to the Rural Workers Association of the Lower Juruá (ASTRUJ) and the ICMBio staff, in particular, Dr. Maria Goretti de Melo Pinto, for their support during fieldwork. We also thank the Amazonas State Research Foundation (FAPEAM) for a graduate stipend.

\section{References}

Araújo-Lima, C.; Goulding, M. Os frutos do tambaqui: ecologia, conservação e cultivo na Amazônia. Tefé, AM: Sociedade Civil Mamirauá; Brasília: CNPq, 1998.

Ayres, J. M. As matas de várzea do Mamirauá. MCT-CNPq/ Sociedade Civil Mamirauá, Brasília, D.F., 1993. 123 p.

Bailey, K. D. Methods of social research. New York: The Free Press, McMillan Publishers, 1982. 553 p.

Barthem, R. B.; Fabré, N. N. Biologia e diversidade dos recursos pesqueiros da Amazônia. In: Ruffino, M. L. (Coord.). A pesca e os recursos pesqueiros na Amazônia brasileira. Manaus: Ibama/ProVárzea. 2004. p. 17-62.

Berlin, B. Ethnobiological Classification: Principles of Categorization of Plants and Animals in Traditional Societies. Princeton University Press, 1992. 335 p.

Braga, T. M. P.; Rebêlo, G. H. Conhecimento tradicional dos pescadores do baixo rio Juruá: aspectos relacionados aos hábitos alimentares dos peixes da região. Interciência,
659-665, 2014. Disponível em: <http://www.interciencia. org/v39_09/index.html>.

Cavalcante, D. P. Marcas de crescimento aplicadas ao estudo da maturação sexual do Aruanã (Osteoglossum bicirrossum, Vandelli, 1929) na Reserva de Desenvolvimento Sustentavél Mamirauá, Amazonas- Brasil. 55 p. Dissertação (Mestrado em Ciência Animal) - Universidade Federal do Pará - UFPA, 2004.

Del-Claro, K. Comportamento Animal: uma introdução à ecologia comportamental. Jundiaí-SP: Distribuidora/Editora - Livraria Conceito, 2004. 134 p. Disponível em: <http:// www.cnpq.br/documents/10157/18337e47-086c-4272-ad55-97099922e04f>.

Ferreira, E. J. G.; Zuanon, J. A. S.; Santos, G. M. Peixes comerciais do médio Amazonas: região de Santarém, Pará. Brasília: Edições IBAMA, 1998. 214 p.

Gomiero, L. M.; Braga, F. M. S. Reproduction of Species of the Genus Cichla in a reservoir in Southeastern Brazil. 
Brazilian Journal of Biology, 64(3B), 613-624, 2004. doi: 10.1590/S1519-69842004000400008

Isaac, V. J.; Rocha, V. L. C.; Mota, S. Q. C. Ciclo reprodutivo de algumas espécies de peixes comerciais do baixo Amazonas. Ibama. Coleção Meio Ambiente. Série Estudos Pesca, 22, 31-64, 2000.

Lima, A. C.; Araújo-Lima, C. A. R. M. The distributions of larval and juvenile fishes in Amazonian rivers of different nutrient status. Freshwater Biology, 49, 787-800, 2004.

Lowe-Mcconnel, R. H. Estudos ecológicos de comunidades de peixes tropicais. Tradução de Anna Emília A. de Vazzoler, Ângelo Antônio Agostinho, Patrícia T. M. Cunhingham. São Paulo: Editora da Universidade de São Paulo, 1999. 534 p. (Coleção Base)

Marques, J. G. W. Aspectos ecológicos na etnoictiologia dos pescadores do Complexo Estuarino-Lagunar Mundaú-Manguaba, Alagoas. 292 p. Tese (Doutorado) - Universidade Estadual de Campinas, 1991.

Marques, J. G. W. O olhar (des)multiplicado. O papel do interdisciplinar e do qualitativo na pesquisa etnobiológica e etnoecológica. In: Amoroso, M. C. L.; Ming, L. C.; Silva, S. P. (Eds.). Métodos de coleta e análise de dados em Etnobiologia, Etnoecologia e disciplinas correlatas. Anais do I Encontro de Etnobiologia e Etnoecologia do Sudeste. São Paulo-SP: UNESP, 2002. p. 31-46.

Minayo, M. C. S. (Org.). Pesquisa social: método e criatividade. Petrópolis, RJ: Vozes, 1998. 80 p.

Morán, E. Ecologia humana das populações da Amazônia. Petrópolis, RJ: Vozes, 1990. p. 367.
Mourão, J. S.; Nordi, N. Etnoictiologia de pescadores artesanais do estuário do Rio Mamanguape, Paraíba, Brasil. Boletim do Instituto de Pesca, 29(1), 9-17, 2003. Disponível em: <ftp://ftp.sp.gov.br/ftppesca/Mourao.PDF>.

Posey, D. A. Introdução à Etnobiologia: teoria e prática. In: Ribeiro, D. Sum. Etnol. Bras., v.1, Etnobiologia. Petrópolis, RJ: Vozes, 1987.

Santos, G. M.; Ferreira, E. J. G. Peixes da Bacia Amazônica. In: Lowe-Mcconnel, R. H. Estudos ecológicos de comunidades de peixes tropicais. Tradução de Anna Emília A. de Vazzoler, Ângelo Antônio Agostinho, Patrícia T. M. Cunhingham. São Paulo: Editora da Universidade de São Paulo, 1999. p 345- 373. (Coleção Base)

Santos, G. M.; Efrem, J. G. F.; Zuanon, J. A. S. Peixes comerciais de Manaus. Manaus: Ibama/AM, Provárzea, 2006. 129 p.

Silvano, R. A. M.; Begossi, A. Ethnoichthyology and fish conservation in the Piracicaba river (Brasil). Journal of Ethnobiology, 22(2), 285-306, 2001.

Souto, F. J. B.; Martins, V. S. Conhecimentos etnoecológicos na mariscagem de moluscos bivalves no Manguezal do Distrito de Acupe, Santo Amaro - BA. Biotemas, 22(4), 207218. 2009. Disponível em: $<$ https://periodicos.ufsc.br/index. php/biotemas/article/view/2175-7925.2009v22n4p207>.

Vazzoler, A. E. A. M. Biologia da reprodução de peixes teleósteos: teoria e prática. Maringá: EDUEM; São Paulo: SBI, 1996. 169 p.

Waizbort, R. Dos genes aos memes: a emergência do replicador cultural. Episteme, 16, 23-44, 2003. 